\title{
Pengaruh Hiperglikemia dan Vitamin E pada Kadar Malonaldehida dan Enzim Antioksidan Intrasel Jaringan Pankreas Tikus
}

\author{
I Nyoman Suarsana, Iwan H. Utama, I Gusti Agung, Ayu Suartini \\ Fakultas Kedokteran Hewan, Universitas Udayana
}

\begin{abstract}
Abstrak
Pencegahan kerusakan jaringan pankreas akibat radikal bebas pada kondisi hiperglikemia kronik sangat penting dan vitamin $\mathrm{E}$ dapat bertindak sebagai pemusnah radikal bebas dalam mencegah perkembangan diabetes melitus. Tujuan penelitian ini untuk mengamati pengaruh vitamin E pada kondisi hiperglikemia pada aktivititas enzim superoxide dismutase (SOD), glutathione peroxidase (GPx), dan kadar malondialdehyde (MDA) pada jaringan pankreas tikus. Penelitian dilakukan di Laboratorium Biokimia Fakultas Kedokteran Hewan Universitas Udayana, tahun 2010. Sebanyak 15 ekor tikus putih jantan strain Spraque Dawley umur 3 bulan digunakan dalam penelitian ini. Tikus percobaan dibagi menjadi tiga kelompok perlakuan. Kelompok kontrol negatif (K0), kelompok tikus hiperglikemia (K1), serta kelompok tikus hiperglikemia dan diberi vitamin E dosis $7 \mathrm{mg} / 200 \mathrm{~g}$ bb/hari (K2). Kelompok hiperglikemia diberi larutan 50\% glukosa, dosis 1,5 cc/ekor per oral dua kali sehari. Perlakuan diberikan selama 1 bulan. Kadar glukosa darah diperiksa menggunakan metode biosensor glukosa oksidase. Enzim SOD, GPx, dan MDA dianalisis menggunakan metode spektrofotometri. Kadar glukosa darah perlakuan K2 sebesar $153,5 \pm 8,2 \mathrm{mg} / \mathrm{dL}$ tidak berbeda $(\mathrm{p}>0,05)$ bila dibandingkan dengan perlakuan $\mathrm{K} 1$ sebesar $154,1 \pm 5,7 \mathrm{mg} / \mathrm{dL}$. Aktivitas SOD perlakuan K2 sebesar 43,21 $13,32 \mathrm{U} / \mathrm{g}$ lebih tinggi dibandingkan dengan perlakuan K1 sebesar $31,99 \pm 3,55 \mathrm{U} / \mathrm{g}(\mathrm{p}<0,05)$. Aktivitas GPx perlakuan K2 sebesar 10,44 $\pm 0,54 \mathrm{U} / \mathrm{g}$ tidak berbeda bermakna $(\mathrm{p}>0,05)$

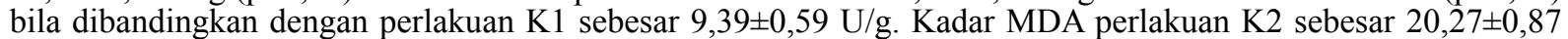
$\mathrm{pmol} / \mathrm{g}$ lebih rendah dibandingkan dengan perlakuan K1 sebesar $25,24 \pm 0,82 \mathrm{pmol} / \mathrm{g}(\mathrm{p}<0,05)$. Simpulan, kadar SOD dan GPx rendah, sedangkan kadar MDA tinggi pada pankreas tikus dalam kondisi hiperglikemia. Pada tikus hiperglikemia yang diberi vitamin E, aktivitas SOD dan GPx tinggi, sedangkan kadar MDA rendah.
\end{abstract}

[MKB. 2011;43(2):72-6].

Kata kunci: Enzim antioksidan, hiperglikemia, pankreas tikus, vitamin E

\section{Hiperglycemic and Vitamin E Effect on Malondialdehyde and Antioxidant Intracellular Enzyme in Rat Pancreatic Tissue}

\begin{abstract}
Prevention of pancreatic tissue damage by free radicals under conditions of hyperglycemia chronic would be important and vitamin $\mathrm{E}$ can act as scavengers of these oxygen radicals in preventing the development of diabetes mellitus. This study aims was to evaluate the effect of vitamin E on the hyperglycemia conditions on the blood glucose, enzyme superoxide dismutase (SOD), glutathione peroxidase (GPx), and malondialdehyde (MDA) levels in rat pancreatic tissue. Research conducted at the Laboratory of Biochemistry Faculty of Veterinary Medicine Udayana University, in 2010. A total of 15 male rats white of strains Spraque Dawley old 3 months used in this study. All of rats were divided into three groups. Negative control group (K0), group of rats hyperglycemia (K1), and group of hyperglycemia and given vitamin E dose of $7 \mathrm{mg} / 200 \mathrm{~g}$ bw/day (K2). Hyperglycemia group was given $50 \%$ glucose solution doses of $1.5 \mathrm{cc} / \mathrm{head}$ orally twice daily. Treatment was conducted for $1 \mathrm{month}$. Blood glucose level was measured by using glucose oxidase biosensor method. Pancreatic SOD, GPx activities, and MDA levels were measured by using spectrophotometric methods. Blood glucose levels in the K2 treatment of $153.5 \pm 8.2 \mathrm{mg} / \mathrm{dL}$ was not significantly different $(\mathrm{p}>0.05)$ when compared with the K1 treatment of $154.1 \pm 5.7 \mathrm{mg} /$ $\mathrm{dL}$. Activities of SOD enzymes in the K2 treatment of 43.21 $\pm 3.32 \mathrm{U} / \mathrm{g}$ higher than the K1 treatment of $31.99 \pm 3.55$ $\mathrm{U} / \mathrm{g}(\mathrm{p}<0.05)$. Activities of GPx enzymes in the K2 treatment of $10.44 \pm 0.54 \mathrm{U} / \mathrm{g}$ was not significantly different ( $>0.05$ ) when compared with K1 treatment of $9.39 \pm 0.59 \mathrm{U} / \mathrm{g}$. MDA level in the K2 treatment of $20.27 \pm 0.87$ $\mathrm{pmol} / \mathrm{g}$ lower than the K1 treatment of $25.24 \pm 0.82 \mathrm{pmol} / \mathrm{g}(\mathrm{p}<0.05)$. In conclusion, SOD and GPx enzymes levels are low whereas MDA level is high in the rat pancreatic under conditions of hyperglycemia. The hyperglycemic rat by treatment with vitamin E shows high SOD and GPx levels and low MDA levels. [MKB. 2011;43(2):72-6].
\end{abstract}

Key words: Enzyme antioxidant, hyperglycemia, pancreatic rat, vitamin E

Korespondensi: I Nyoman Suarsana, Laboratorium Biokimia, Fakultas Kedokteran Hewan, Universitas Udayana, jalan PB. Sudirman, Denpasar Bali, e-mail: suarsana65@yahoo.com 


\section{Pendahuluan}

Kebanyakan populasi di belahan dunia mengonsumsi karbohidrat dalam jumlah besar. Hal ini terjadi karena karbohidrat menyediakan sebagian besar energi dalam diet. ${ }^{1}$ Diet karbohidrat yang berlebihan menyebabkan terjadinya hiperglikemia. Hiperglikemia adalah keadaan kadar glukosa di dalam darah melebihi kadar glukosa darah normal. Pada manusia, kadar glukosa darah normal puasa 80-110 mg/dL, ${ }^{2}$ dan pada tikus kadar glukosa darah normal 95-125 mg/dL. ${ }^{3}$

Keadaan hiperglikemia kronik cenderung menimbulkan efek yang tidak baik bagi kesehatan tubuh, sebab kadar glukosa yang tinggi cenderung mendorong terbentuknya radikal bebas atau spesies oksigen reaktif melalui mekanisme oksidasi reduksi dengan mendorong lebih banyak donor elektron (NADH dan FADH2) ke dalam rantai transpor elektron di mitokondria. ${ }^{4}$

Sumber radikal bebas terbesar terjadi selama proses transpor elektron dengan menghasilkan radikal bebas anion superoksida dan produksinya dapat meningkat dalam keadaan hiperglikemia. ${ }^{5}$ Anion superoksida diubah menjadi hidrogen peroksida dan selanjutnya masuk ke dalam membran sel dan dapat menyebabkan kerusakan jaringan pankreas. Selain itu pada proses autooksidasi glukosa juga dihasilkan radikal bebas hidroksil. ${ }^{6}$ Radikal bebas menyebabkan terjadinya reaksi peroksidasi lipid dengan membentuk malondialdehida (MDA) dan kadar MDA yang tinggi dapat digunakan sebagai penanda kerusakan oksidatif.

Berbagai organ tubuh, termasuk jaringan pankreas memiliki mekanisme sistem pertahanan alami berupa enzim antioksidan intrasel atau endogen, yaitu superoksida dismutase (SOD), catalase (Cat), dan glutathione peroxidase (GPx) yang berperan sebagai lini pertahanan terdepan berfungsi menetralkan dan mempercepat degradasi senyawa radikal bebas untuk mencegah kerusakan komponen makromolekul sel. ${ }^{8}$ Kadar antioksidan enzim intrasel atau endogen jaringan pankreas dapat dipengaruhi oleh radikal bebas serta asupan antioksidan eksogen, seperti vitamin A, vitamin C, vitamin $\mathrm{E}$, dan senyawa antioksidan eksogen.

Pankreas tikus dewasa berisi kira-kira 1-2\% pulau-pulau Langerhans dari luas pankreas. Stuktur membran sel pankreas tersusun atas fosfolipid, asam lemak tidak jenuh, dan protein. Komponen membran tersebut sangat sensitif terhadap oksidasi. ${ }^{3}$ Oleh karena itu, antioksidan lipofilik harus memainkan peran khusus dalam sistem perlindungan antioksidatif pada jaringan pankreas.

Vitamin E adalah vitamin yang larut dalam lemak terdiri atas dua isomer, yaitu tokoferol dan tokotrienol. Tokoferol alfa adalah bentuk yang paling aktif dan merupakan antioksidan dalam plasma dan jaringan sebagian besar manusia. ${ }^{9}$

Antioksidan vitamin E berfungsi untuk memutuskan reaksi rantai radikal dan berpotensi sebagai scavenger radikal peroksil. ${ }^{8}$ Jika lipid hidroperoksida dioksidasi menjadi radikal peroksil ( $\left.\mathrm{ROO}^{-}\right)$, radikal ini bereaksi seribu kali lebih cepat dengan vitamin E dibandingkan dengan asam lemak tidak jenuh polyunsaturated fatty acids (PUFA). Hal ini disebabkan adanya gugus hidroksil fenolik pada cincin kromanol vitamin E bereaksi dengan radikal peroksil membentuk senyawa yang lebih stabil. ${ }^{10}$ Dengan demikian, diharapkan vitamin $\mathrm{E}$ dapat mencegah efek negatif kerusakan oksidatif akibat hiperglikemia. Tujuan penelitian ini untuk mengamati pengaruh kondisi hiperglikemia dan pemberian vitamin E pada aktivititas enzim SOD, GPx, dan kadar malonaldehida pada jaringan pankreas tikus.

\section{Metode}

Sebanyak 15 ekor tikus putih jantan strain Spraque Dawley umur 3 bulan dengan bobot badan 200-215 g, dikelompokkan menjadi 3 kelompok perlakuan. Kelompok kontrol negatif (K0), kelompok hiperglikemia (K1), serta kelompok hiperglikemia yang diberi vitamin $\mathrm{E}$ (Evion $\AA$, Merck) dosis 7 $\mathrm{mg} / 200 \mathrm{~g} / \mathrm{bb} /$ hari (K2). Perlakuan hiperglikemia dilakukan berdasarkan hasil penelitian pendahuluan, yaitu dengan cara tikus diberi larutan $50 \%$ glukosa murni dosis $1,5 \mathrm{cc} / \mathrm{ekor}$ dua kali sehari secara oral (pagi jam 08.00 dan sore jam 18.00). Perlakuan diberikan selama 1 bulan. Pada akhir perlakuan, tikus dianestesi dengan obat bius ketamin- $\mathrm{HCl}$, kemudian darah diambil melalui jantung. Tikus dibedah dan jaringan pankreas diambil untuk pemeriksaan enzim antioksidan intrasel.

Kadar glukosa darah diukur untuk menentukan keadaan hiperglikemia. Kadar glukosa darah tikus percobaan ditentukan dengan metode biosensor glukosa oksidase, menggunakan alat blood glucose test meter glucoDr ${ }^{\mathrm{TM}}$ model AGM-2100 (diproduksi oleh allmedicus Co Ltd., Korea). Sebelum dianalisis, hewan dipuasakan selama 12 jam. Darah diambil melalui ujung ekor tikus yang sebelumnya dibersihkan dengan alkohol $70 \%$, kemudian ujung ekor ditusuk dengan jarum kecil. Darah yang keluar kemudian disentuhkan pada strip glukometer. Setelah 11 detik, kadar glukosa darah akan terbaca di layar GlucoDr ${ }^{\mathrm{TM}}$ dan dinyatakan dalam satuan $\mathrm{mg} / \mathrm{dL}$.

Aktivitas enzim SOD dianalisis menggunakan metode menurut Nebot dkk. ${ }^{11}$ Sebanyak $400 \mu \mathrm{L}$ larutan kloroform/etanol dingin 37,5/62,5 (v/v) ditambahkan ke dalam $150 \mu \mathrm{L}$ lisat pankreas, selanjutnya divorteks selama 3 detik dan disen- 
trifus pada kecepatan $4.400 \mathrm{rpm}$ suhu $4^{\circ} \mathrm{C}$ selama 10 menit. Sebanyak $50 \mu \mathrm{L}$ larutan sampel atau baku (kontrol) ditambah 2,9 mL larutan A (campuran larutan xantin dan larutan sitokrom c) dan divorteks secara perlahan. Selanjutnya ditambah $50 \mu \mathrm{L}$ larutan B (xantin oksidase) dan divorteks secara perlahan. Kemudian absorbansi diukur menggunakan spektrofotometer pada $\lambda 550 \mathrm{~nm}$.

Aktivitas enzim GPx dianalisis menggunakan metode menurut Pigeolet dkk. ${ }^{12}$ Sebanyak 100 $\mu \mathrm{L}$ homogenat pankreas ditambah dengan $200 \mu \mathrm{L}$ bufer fosfat $\mathrm{pH} 7$ lalu dihomogenkan (divorteks). Homogenat disentrifus pada $4.000 \mathrm{rpm} 4^{\circ} \mathrm{C}$ selama 5 menit. Supernatan diambil untuk diukur aktivitas enzim glutation peroksidase. Sebanyak $200 \mu \mathrm{L} \mathrm{0,1} \mathrm{M} \mathrm{bufer} \mathrm{fosfat} \mathrm{pH}$ 7,0 mengandung $0,1 \mathrm{mM}$ EDTA ditambahkan dengan $200 \mu \mathrm{L}$ sampel, $200 \mu \mathrm{L} 10 \mathrm{mM}$ glutation tereduksi (GSH) dan $200 \mu \mathrm{L}$ enzim glutation reduktase 2,4 unit. Semua campuran larutan diinkubasi selama 10 menit pada suhu $37^{\circ} \mathrm{C}$. Selanjutnya ke dalam larutan ditambahkan $200 \mu \mathrm{L}$ 1,5 mM NADPH dan diinkubasi lagi pada suhu $37^{\circ} \mathrm{C}$ selama 3 menit, kemudian ditambahkan $200 \mu \mathrm{L} 1,5 \mathrm{mM}$ $\mathrm{H}_{2} \mathrm{O}_{2}$. Serapan dibaca $1-2$ menit pada $\lambda 340 \mathrm{~nm}$.

Kadar MDA dianalisis menggunakan metode menurut Capeyron dkk. ${ }^{13}$ Sebanyak $\pm 0,5$ g pankreas segar dicacah dalam kondisi dingin dalam 2,5 mL larutan PBS yang mengandung 11,5 g/L KCl. Homogenat disentrifugasi pada $4.000 \mathrm{rpm}$ selama 10 menit. Sebanyak 0,5 mL sampel atau standar ditambah dengan $2 \mathrm{~mL}$ campuran $\mathrm{HCl} 0,25 \mathrm{~N}$ dingin yang mengandung $15 \%$ thricloro acetic acid (TCA), 0,38\% thio barbituric acid (TBA) dan 0,5\% butylated hydroxytoluene (BHT). Campuran larutan ini dipanaskan $80{ }^{\circ} \mathrm{C}$ selama 1 jam. Setelah dingin, campuran larutan dan standar disentrifugasi $3.500 \mathrm{rpm}$ selama 10 menit. Absorbansi supernatan diukur pada $\lambda 532 \mathrm{~nm}$. Sebagai larutan standar digunakan 1,1,3,3-tetraetoksipropana (TEP).

Rancangan percobaan menggunakan rancangan acak lengkap (RAL). Data yang diperoleh dianalisis dengan analysis of variance (ANOVA). Jika perlakuan memberikan pengaruh yang nyata, maka pengujian dilanjutkan dengan uji beda Duncan pada taraf 5\% untuk mengetahui pengaruh antar perlakuan. ${ }^{14}$

\section{Hasil}

Hasil pengamatan terhadap kadar glukosa darah, kadar enzim antioksidan intraselular (SOD, GPx), dan kadar peroksidasi lipid (MDA) pankreas tikus percobaan dapat dilihat pada tabel.

Pada tabel terlihat kadar glukosa darah kelompok perlakuan hiperglikemia (K1) sebesar $154,1 \mathrm{mg} / \mathrm{dL}$ tidak berbeda bermakna dengan perlakuan hiperglikemia yang diberi vitamin $\mathrm{E}$ (K2) 153,5 mg/dL, akan tetapi kadar glukosa darah kedua kelompok tersebut lebih tinggi dan berbeda nyata $(\mathrm{p}<0,05)$ apabila dibandingkan dengan kelompok kontrol (K0) sebesar 107,9 mg/dL.

Aktivitas kedua enzim antioksidan intraselular, baik SOD maupun GPx lebih kecil pada perlakuan hiperglikemia (K1) dengan nilai SOD sebesar 31,99 U/g dan GPx sebesar 9,39 U/g. Di antara kedua enzim tersebut, SOD nyata $(p<0,05)$ lebih rendah apabila dibandingkan dengan kelompok perlakuan lainnya, sementara aktivitas GPx pada ketiga kelompok perlakuan tidak berbeda nyata $(p>0,05)$. Apabila dibandingkan dengan kelompok perlakuan hiperglikemia dan vitamin E (K2), aktivitas kedua enzim hanya sedikit lebih rendah, yaitu SOD sebesar 43,21 U/g serta GPx 10,44 U/g dan tidak berbeda bermakna dengan kelompok kontrol (K0), yaitu SOD sebesar 45,87 U/g dan GPx sebesar 11,24 U/g.

Berbeda dengan aktivitas enzim antioksidan intraselular, justru kadar MDA pankreas meningkat pada perlakuan hiperglikemia (K2) sebesar 25,24 $\mathrm{pmol} / \mathrm{g}$ dan berbeda bermakna $(\mathrm{p}<0,05)$ apabila dibandingkan dengan kelompok perlakuan lainnya. Pada kedua kelompok lainnya, yaitu kelompok hiperglikemia yang mendapat vitamin E (K2) serta kelompok kontrol negatif(K0) kadar MDA pankreas tidak berbeda bermakna ( $\mathrm{p}>0,05)$, masing-masing sebesar 20,27 pmol/g dan 19,57 pmol/g.

\section{Pembahasan}

Hiperglikemia yang berlangsung lama dapat menimbulkan efek negatif terhadap jaringan. Kondisi hiperglikemia kronik ini disebut juga sebagai toksisitas glukosa, ${ }^{6}$ yaitu paparan kronik

Tabel Kadar Glukosa Darah, Enzim SOD, GPx, dan MDA Pankreas Tikus Percobaan

\begin{tabular}{lccc}
\hline \multicolumn{1}{c}{ Parameter } & \multicolumn{3}{c}{ Perlakuan } \\
\cline { 2 - 4 } & K0 & K1 & $153,5 \pm 8,2^{\mathrm{a}}$ \\
\hline Glukosa darah (mg/dL) & $107,9 \pm 7,1^{\mathrm{b}}$ & $154,1 \pm 5,7^{\mathrm{a}}$ & $43,21 \pm 3,32^{\mathrm{a}}$ \\
SOD (U/g) & $45,87 \pm 3,81^{\mathrm{a}}$ & $31,99 \pm 3,55^{\mathrm{b}}$ & $10,44 \pm 0,54^{\mathrm{a}}$ \\
GPx (U/g) & $11,24 \pm 0,75^{\mathrm{a}}$ & $9,39 \pm 0,59^{\mathrm{a}}$ & $20,27 \pm 0,87^{\mathrm{b}}$ \\
MDA (pmol/g) & $19,57 \pm 0,94^{\mathrm{b}}$ & $25,24 \pm 0,82^{\mathrm{a}}$ & \\
\hline
\end{tabular}

Keterangan: Nilai dengan superskrip berbeda pada baris yang sama menunjukkan berbeda secara nyata ( $<0,05)$. KO (kontrol negatif), K1 (kelompok hiperglikemia), K2 (kelompok hiperglikemia dan diberi vitamin E) 
kadar glukosa tinggi dianggap sebagai kekuatan patogen yang mengarah kepada toksisitas sel. Lebih lanjut dijelaskan, hiperglikemia kronik dapat menimbulkan stres oksidatif. Stres oksidatif didefinisikan sebagai suatu keadaan kadar prooksidan lebih tinggi dibandingkan dengan kadar enzim antioksidan serta dapat memicu penuaan dini dan kematian sel. ${ }^{15}$

Pada penelitian ini, kadar enzim SOD dan GPx lebih kecil pada kelompok perlakuan hiperglikemia (K1). Hal ini karena pada kondisi hiperglikemia terjadi pembentukan radikal bebas yang lebih tinggi bila dibandingkan dengan keadaan normal. Meskipun dalam penelitian ini radikal bebas tidak diukur, tetapi tingginya kadar MDA yang dihasilkan pada kelompok K1 dapat digunakan sebagai penanda kerusakan oksidatif akibat radikal bebas. Pada kondisi fisiologis normal, glukosa akan mengalami proses glikolisis dan fosforilasi oksidatif, akan tetapi pada kondisi hiperglikemia, glukosa mengalami metabolisme melalui jalur alternatif, yaitu jalur autooksidasi glukosa, serta glikasi dan pembentukan dikarbonil. ${ }^{16}$ Metabolisme lewat jalur tersebut akan menghasilkan radikal bebas hidroksil $\left(\mathrm{OH}^{-}\right)$dan radikal superoksida $\left(\mathrm{O}^{-}{ }^{-}\right)$. Pembentukan radikal bebas yang berlebih tersebut tidak mampu dinetralkan atau dimusnahkan (scavenger) oleh kedua enzim tersebut, sehingga jika dianalisis kadar MDA akan lebih rendah bila dibandingkan dengan kelompok kontrol negatif (K1).

Sel endotel yang dipapar dengan $30 \mathrm{mM}$ glukosa sudah menyebabkan hambatan terhadap aktivitas gliseraldehyde phosphate dehydrogenase (GAPDH) oleh poly ADP-ribose polymerase (PARP). Hambatan terhadap kerja enzim GAPDH dapat mengalihkan metabolisme glukosa ke jalur yang dapat menghasilkan radikal bebas. ${ }^{6}$

Konsep kelebihan glukosa dapat menimbulkan oksidatif stres melalui jalur alternatif, diteliti oleh Takahashi dkk. ${ }^{7}$ Pada percobaan pankreas tikus yang diberi konsentrasi $2 \mathrm{mMol}$ d-gliseraldehida yang tinggi, pembentukan radikal bebas dapat diamati setelah 24 jam perlakuan dan ini dikaitkan dengan penurunan kadar insulin serta keadaan hiperglikemia. Menurut Poitout dan Robertson, ${ }^{17}$ kondisi hiperglikemia dan glukolipotoksisiti merupakan fenomena sekunder yang mendasari timbulnya diabetes melitus tipe 2 .

Rendahnya aktivitas enzim SOD dan GPx sejalan dengan ditemukannya kadar MDA yang tinggi pada kelompok hiperglikemia (K1). Tingginya kadar MDA kelompok hiperglikemia, menunjukkan bahwa status enzim antioksidan rendah, sehingga tidak dapat mencegah reaktivitas senyawa radikal bebas. Reaktivitas tersebut ditandai dengan terjadinya reaksi peroksidasi lipid dengan terbentuk lebih banyak malondialdehida (MDA). Produk MDA dapat diukur sebagai indeks tidak langsung kerusakan oksidatif yang disebabkan oleh peroksidasi lipid.

Pada kelompok perlakuan hiperglikemia (K1) aktivitas enzim SOD dan GPx pada pankreas lebih kecil, hal ini disebabkan karena pembentukan radikal bebas yang berlebih. Pankreas mengandung enzim antioksidan utama, seperti SOD, katalase, dan GPx jauh lebih sedikit dibandingkan dengan organ lain seperti hati, ginjal, dan otot. Oleh karena itu, sangat kuat dugaan bahwa hiperglikemia kronik dapat menurunkan kadar kedua enzim tersebut. ${ }^{6}$ Enzim yang berfungsi sebagai enzim antioksidan endogen dapat menurun aktivitasnya apabila terbentuk radikal bebas dalam jumlah berlebihan. ${ }^{15}$ Enzim SOD dan GPx merupakan enzim endogen yang terdapat di dalam sel yang berperan sebagai lini pertahanan pertama terhadap radikal bebas dengan cara membersihkan radikal bebas (free radical scavenger) dengan reaksi enzimatis dan mengubahnya menjadi bentuk yang lebih stabil. ${ }^{8}$

Pengamatan yang menarik bahwa glukosa konsentrasi tinggi dapat menyebabkan stres selular pada pankreas yang ditunjukkan dengan kenaikan radikal bebas dan menyebabkan aktivitas enzim antioksidan menjadi rendah. ${ }^{16}$

Hasil berbeda diperlihatkan pada kelompok perlakuan hiperglikemia yang mendapat vitamin E (K2). Pada kelompok ini, baik kadar MDA, kadar enzim SOD dan GPx lebih rendah dibandingkan dengan kelompok hiperglikemia (K1). Hal ini disebabkan aktivitas vitamin $\mathrm{E}$ dapat bertindak sebagai antioksidan. Vitamin E merupakan golongan antioksidan fenolik dan mempunyai pengaruh sinergis dengan enzim SOD dan GPx. Aktivitas keduanya secara langsung dapat melindungi sel dengan kemampuannya sebagai scavenger radikal bebas.

Dari berbagai laporan penelitian, diketahui bahwa efek negatif dari senyawa radikal dapat diredam oleh antioksidan, baik berupa zat gizi vitamin A, C, dan E maupun golongan flavonoid. ${ }^{8}$ Hasil penelitian Kuribayashi dkk..$^{18}$ menyatakan bahwa pemberian vitamin $\mathrm{E}$ dapat mengurangi pembentukan MDA dan kerusakan pembuluh darah pada kelinci akibat stres oksidatif yang diinduksi dengan kortikosteroid.

Vitamin E berperan sebagai antioksidan primer karena kemampuannya sebagai scavenger radikal bebas dan memutus reaksi berantai dengan radikal peroksil dengan cara menyumbangkan satu atom hidrogen. ${ }^{10}$ Hal yang sama juga dilaporkan bahwa vitamin E, khususnya $\alpha$-tokoperol berfungsi sebagai antioksidan pemutus reaksi rantai radikal, ${ }^{8}$ serta berpotensi sebagai scavenger singlet oksigen dan spesies reaktif lainnya melalui transfer satu atom hidrogen dari gugus 6-hidroksil pada cincin kromanol. ${ }^{19}$

Sebagai antioksidan, vitamin E bersama- 
sama enzim SOD dan GPx berperan dalam memperlambat dan mencegah berlangsungnya reaksi peroksidasi lipid, sehingga produk MDA menjadi rendah. Dengan kata lain, pemberian vitamin E pada kelompok K2 membantu kerja enzim SOD dan GPx dalam mengatalisasi secara ezimatis kelebihan radikal bebas menjadi produk lain yang lebih stabil, sehingga kadar SOD dan GPx dalam jaringan pankreas menjadi lebih terjaga dan tidak mengalami penurunan yang drastis.

Hasil penelitian dapat disimpulkan, bahwa kadar SOD dan GPx rendah, sedangkan kadar MDA tinggi pada pankreas tikus dalam kondisi hiperglikemia. Pada tikus hiperglikemia yang diberi vitamin E menunjukkan aktivitas SOD dan GPx tinggi, sedangkan kadar MDA rendah.

\section{Daftar Pustaka}

1. Irawan MA. Karbohidrat. Sport Science Brief. 2001;1(3):1-5.

2. Wijayakusuma H. Bebas diabetes mellitus. Jakarta: Puspa Swara; 2004.

3. Gulfraz M, Qadir G, Noshhen F, Parveen Z. Antihyperglycemic effects of Berberis lyceum royle in alloxan induced diabetic rats. Diabetologia Croatica. 2007;36(3):49-54.

4. Brownlee M. Biochemistry and molecular cell biology of diabetic complications. Nature. 2001;414:813-20.

5. Robertson RP, Harmon J, Tran PO, Tanaka Y, Takahashi H. Glucose toxicity in betacells: type 2 diabetes, good radicals gone bad, and the glutathione connection. Diabetes. 2003;52:581-7.

6. Robertson RP, Harmon J, Tran PO, Poitout V. $\beta$-cell glucose toxicity, lipotoxicity, and chronic oxidative stress in type 2 diabetes. Diabetes. 2004;53:S119-24.

7. Takahashi H, Tran PO, LeRoy E, Harmon JS, Tanaka Y, Robertson RP. d-Glyceraldehyde causes production of intracellular peroxide in pancreatic islets, oxidative stress, and defective-cell function via non-mitochondrial pathways. J Biol Chem. 2004;279:37316-23.

8. Valko M, Leibfritz D, Moncol J, Cronin MTD, Mazur M, Telser J. Review: free radicals and antioxidants in normal physiological functions and human disease. Inter J Biochem Cell Biol. 2007;39:44-84.

9. Stolzenberg-Solomon RZ, Sheffler-Collins S, Weinstein S, Garabrant DH, Mannisto S, Taylor P, dkk. Vitamin E intake, $\alpha$-tocopherol status, and pancreatic cancer in a cohort of male smokers. Am J Clin Nutr. 2009;89: 584-91.

10. Pokorny J, Yanihlieva N, Gordon M. Antioxidants in food. England: CRC press. Woodhead Publishing Limited; 2001.

11. Nebot C, Moutet M, Huet P, Xu JZ, Yadan JC, Chaudiere J. Spectrophotometric assay of superoxide dismutase activity based on the activated autooxidation of a tetracyclic catechol. Analytical Biochem. 1993;214: 442-51.

12. Pigeolet E, Phillippe C, Andree H, Dominique L, Carine M, Martine R, dkk. Glutathione peroxidase, superoxide dismutase and catalase inactivation by peroxides and oxygen derived free radicals. Mechanism Aging Development. 1990;51:283-97.

13. Capeyron MFM, Julie C, Eric B, Jean P, Jean MR, Piere B, dkk. A diet cholesterol and deficient in vitamin $\mathrm{E}$ induces lipid peroxidation but does not enhace antioxidant enzyme expression in rat liver. J Nutr Biochem. 2002;13:296-301.

14. Steel RGD, Torrie JH. Prinsip dan prosedur statistika, suatu pendekatan biometrik. Jakarta: PT. Gramedia Pustaka Utama; 1993.

15. Halliwell B. Reactive spesies and antioxidants: redox biology is a fudamental theme of aerobic life. Plant Physiol. 2006; 141:312-22.

16. Robertson RP. Chronic oxidative stress as a central mechanism for glucose toxicity in pancreatic islet beta cells in diabetes. J Biol Chem. 2004;279(41):42351-4.

17. Poitout V, Robertson RP. Glucolipotoxicity: fuel excess and-cell dysfunction. Endocrine Rev. 2008;29(3):351-66.

18. Kuribayashi M, Fujioka M, Takahashi KA, Arai Y, Ishida M, Goto T, dkk. Vitamin E prevents steroid-induced osteonecrosis in rabbits. Acta Orthopaedica. 2010;81(1):15460.

19. Muchtadi D. Gizi anti penuaan dini. Bandung: Penerbit Alfabeta; 2009. 